\title{
Translation Strategies for Chinese Higher Education Institutes' Website Publicity
}

\author{
Yuhong Huang \\ College of Humanities and Law \\ Fujian Agriculture and Forestry University \\ Fuzhou, Fujian, China \\ 47098368@qq.com
}

\author{
Yiying Chen \\ Xiamen Yiwai Jingjie Culture and Media Co. Ltd. \\ Xiamen, Fujian, China
}

\begin{abstract}
Website publicity, an important window for expanding Chinese universities' international influence, contributes to the reputation of Chinese higher education institutes in the age of globalization. This paper interprets the translation process and the translational eco-environment from the perspective of Eco-Translatology before exploring the concrete translation strategies for university's website publicity. It argues that translator should make adaptive selections and transformations in at least three dimensions - linguistic dimension, cultural dimension and communicative dimension so as to produce a target text with a higher degree of holistic adaptation and selection.
\end{abstract}

Keywords-three-dimensional transformations; Ecotranslatology; translational eco-environment; website publicity

\section{INTRODUCTION}

Nowadays, more and more Chinese universities are putting efforts in setting up English websites for promoting international academic communication and cooperation. Campus news, one of the key channels for universities to publicize their information to potential overseas audience, is of great significance to establish good images for universities as well as to promote their reputations and to attract more talents and students.

This thesis takes English translation of "News and Events" on the websites of some Chinese universities as examples and explores translation strategies for university webpage news from the perspective of Eco-Translatology.

\section{TRANSLATION PROCESS OF UNIVERSITIES' WEBPAGE NEWS}

According to Hu Gengshen, translation is defined as "a translator's adaptation and selection activities in a translational eco-environment" [1]. Translator, the central figure in the process of translating, produces target texts by natural selection through his adaptation to the translational ecoenvironment and the transplantation of source texts (Figure 1) [2].

From the perspective of Eco-Translatology, the translation process can be expressed by a formula: Translation=Adaptation + Selection. When it comes to the translation process of university webpage news, the formula can be illustrated by Figure 2 .

This paper is sponsored by 2016 Fujian Education and Research Project (JAS160167).

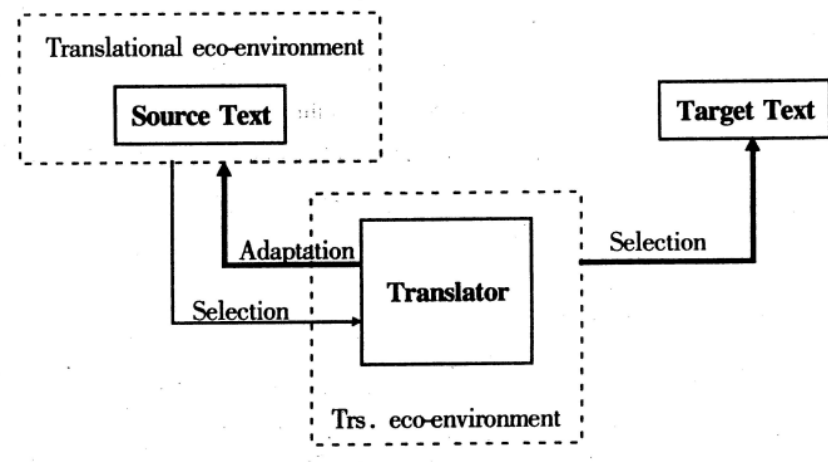

Fig. 1. Translator's adaptation and selection in translation

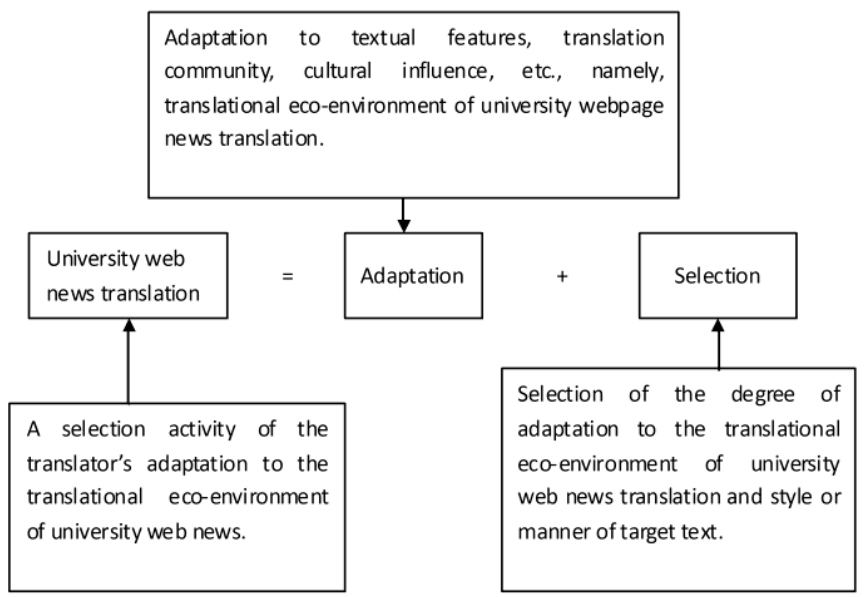

Adaptation and selection on the formula are both dominated by translator-centeredness.

Fig. 2. Translation process of university webpage news

Therefore, the translation process of university webpage news can be described as the process that the translator firstly adapts to the translational eco-environment and then makes adaptive selections on the translational eco-environment and selects the most appropriate target text. 


\section{TRANSLATIONAL ECO-ENVIRONMENT OF UNIVERSITY} WEBPAGE NEWS

Adapting to the translational eco-environment is the prior step for producing a satisfactory target text. In the process of translating university webpage news, translator ought to have a comprehensive understanding of the translational ecoenvironment, which is interpreted as "the worlds of source text and the source/target languages, comprising the linguistic, communicative, cultural and social aspects of translating, as well as the author, the client, and the readers" [1]. Among all the components, textual ecology and audience exert a relatively larger influence on the translation process.

\section{A. Textual Ecology of University Webpage News}

Textual ecology refers to the environment in which the source and target texts function. As a vital component of campus culture, university webpage news always covers academic trends, scientific researches, school achievements and international exchange and cooperation. Therefore, except for accuracy and timeliness, two universal features of news, university webpage news also has its own characteristics as follows:

- Academic contents: campus news directly reports and reflects academic achievements, course and discipline development and scientific researches;

- Interactivity: campus news interact closely with its target readers, that is, the people who (intend to) study and work in the university.

\section{B. Audience of University Webpage News Translation}

Nord contends that "one of the most important factors determining the purpose of a translation is the addressee, who is the intended receiver or audience of the target text with their culture-specific world-knowledge, their expectations and their communicative needs" [3]. Audience is the final target receiver as well as the necessary component of the translational eco-environment. It is obligatory to understand who the audience are to produce a qualified target text. Generally speaking, the audience of university webpage news include:

- Overseas students who plan to study in the university;

- Overseas scholars who intend to work in the university as visiting scholars or experts;

- $\quad$ Exchange students on the campus;

- Overseas alumni of the university.

Due to the different nature of the audience, translator ought to make distinction between domestic publicity and overseas publicity. In the process of translating, translator needs to fully understand the basic principles of publicity to cater to the target audience's expectation and psychology. Translator should also bear in mind which parts are for domestic readers and which parts are for international publicity. After having a sound understanding of the target audience, the translator will be better prepared for the process of university website publicity and will make appropriate adaptation and selection.

\section{Translator's Adaptation and Selection in University Website Publicity}

Translator's adaptation and selection takes a significant position in the translation process of university webpage news.

In the adaptation stage, if the translator is familiar with the university, it will be easier for him or her to produce a satisfactory target text, for he or she can have the opportunities to know detailed aspects of relevant information about the news, so that the target text will be of interest to target community. In addition, the translator needs to adapt to the disparities between Chinese and English linguistic structures, cultures, ideology, readers' expectation, etc.

In the selection stage, translator ought to make selections from at least three aspects: translation method, translation strategy and translation style based on adaptation to the translational eco-environment. In other words, if it is obligatory to retain the features of Chinese culture in the news, the translator should select literal translation with necessary explanations. If there is too much information that are unacceptable to target culture (such as the attendants of a meeting whose names are unfamiliar to the target readers), translator can choose to omit some redundant messages. As for the style, the translator should make flexible choices between formal and informal styles.

To put it in a nutshell, all selections translator makes in the translation process must adapt to the translational ecoenvironment of university webpage news.

\section{TRANSLATION STRATEGIES OF UNIVERSITY WEBPAGE NEWS IN LIGHT OF THREE-DIMENSIONAL TRANSFORMATIONS}

Most of university webpage news belongs to hard news, which is recognized as "having a high level of newsworthiness or news value (usually regarding politics, economics and social matters) demanding immediate publication" [4]. It is desirable for translator to draw great attention to the characteristics of university webpage news including "preciseness and perspicuity, timeliness, selectivity and intentionality" [5] so as to adapt to the translational ecoenvironment.

The translation principles of Eco-translatology can be summarized as "three-dimensional transplantations" [6], that is, under the direction of the principle of multi-dimensional adaptation and adaptive selection, the translator should relatively concentrate more on the adaptive selection and transformation in linguistic dimension, cultural dimension and communicative dimension.

\section{A. Translator's Adaptive Selection and Transformation in Linguistic Dimension}

Nida points out that "a translator must engage in thousands of decisions involving both selection and arrangement to fit another culture, a different language, diverse editors and publishers, and finally a reading audience" [7]. Translator's adaptive selection and transformation in linguistic dimension 
refers to the adaptive selection and transformation in linguistic forms in target text. Specifically speaking, translator should be very familiar with the characteristics of target text and target readers' preference of linguistic expressions. In university webpage news translation, translator should adapt to the linguistic features of English news, that is, being concise and to the point, to cater to target community.

Example 1: 他强调, 海外学院要加大引进优质教育资 源力度, 不断提高办学质量, 让学生满意, 让家长满意, 让社会满意。

He emphasized, School of Overseas Education should increase the intensity of the introduction of high quality educational resources and continuously improve the quality of education, making the students satisfied, parents satisfied, and society satisfied.

Example 2: 此次异地教学活动将有利于进一步推动两 校教育交流与合作，促进跨文化交流，增进两校学生对中 美两国不同文化的认识和理解。

It is expected that through the program education exchange and cooperation and cross-culture communication will be further promoted for two universities.

In Example 1, the phrase in italic is a Chinese expression in a parallel pattern to achieve emphasis. However, the repetition will be regarded as redundant in target text. It will suit the target language conventions better if the translation is revised as "to meet the requirements and expectations of students, parents and society".

In Example 2, the words in italic is the subject in the source text, but in the target text there is an "it" serving as the formal subject, while "education exchange and cooperation and cross-culture communication" is the real subject. Translated in this way, the subject of the sentences is more distinct, allowing readers to catch the main ideas easily. At the same time, it makes the target text more objective, conforming to the stylistic features of news language.

\section{B. Translator's Adaptive Selection and Transformation in Cultural Dimension}

Cultural factors have a great impact on translation, which is particularly true in global communication due to the reason that "knowledge of target audience's cultural background will surely help a communicator sense where to expect common ground, when to be aware of differences, what will elicit feelings of affinity and approval and why something may cause irritation and rejection" [8]. News translation is a transformation activity based on different social cultural background and reflects different cultural phenomena. Therefore, the translator should realize that members of the target-language community may not share what is considered general knowledge in the source language culture, and necessary explanation for culture-loaded terms is essential to ensure the success of information communication.

Example 3: 近日，药学院 “干人计划”专家XXX 教授 在《科学》杂志 (Science) 子刊 Science Signaling 发表特约 评论文章。
Suggested translation: Recently, Prof. XXX, one of the "Thousand Talents Plan" experts (also known as "The Recruitment Program of Global Experts", which calls for strategic scientists or leading talents who can make breakthroughs in key technologies or can enhance China's high-tech industries and emerging disciplines) from the School of Pharmaceutical Sciences, published a special review article in Science Signaling.

Example 4: 1 月 10 日上午，第三届德班孔院 “汉语 桥”大学生赴华冬令营结业仪式在明德楼龙岩厅顺利举 行。

Suggested translation: The graduation ceremony for the Third "Chinese Bridge Winter Camp" of DUT Confucius Institute was held on January 10, 2017. The Chinese Bridge Winter Camp, an annual activity held by FAFU and Confucius Institute at DUT, aims to enhance China-South Africa youth exchanges, deepen the understanding of Chinese language, culture, tradition, and history and stimulate the passion for learning Chinese through a combination of classroom study and excursions.

In Example 3, “千人计划” is a project held by Organization Department of the CPC Central Committee, aiming at inviting global talents in different fields to support the development of China. If the translator translates it without any explanatory note, confusion may arise. Instead, the translator applies contextual explanation to make the readers understand the underlying cultural implication of the term.

In Example 4, "Chinese Bridge" is an unfamiliar term to foreign readers. Literal translation alone will not offer adequate information for the target readers. Therefore, the suggested translation adopts the strategy of pragmatic explicitation to elaborate the connotation and help the target readers achieve coherent understanding of the translation.

\section{Translator's Adaptive Selection and Transformation in Communicative Dimension}

Translator should also make adaptive selection and transformation in communicative dimension. The translator needs to ensure that the communicative function of the source text can be reproduced in the target text. The final target of news translation is to build a bridge between the domestic university and foreign readers, offering information for potential overseas students and scholars, publicizing the university as well as enhancing communication and cooperation. So translator must make sure that the information of the news will be conveyed in a manner that fits the target community's reading habits and make them get the same information as the readers of source text do as much as possible.

Example 5: 我校召开国家留学基金委优秀本科生国际 交流项目候选人选拔推荐工作会议。

FAFU's Undergraduate Applicants for CSC Scholarship Nailed Down

Example 6: 驻卢旺达大使 $X X$ 、政治参赞 $X X$ 、卢农业 部常秘 $X X X$, 卢农业部农业署长 $X X X$, 我援卢农业技术示 
范中心专家组组长 $X X X$ 、中国地质卢旺达分公司总经理 $X X X$ 出席开园仪式。

Suggested translation: Related officials and experts from both countries, including $\mathrm{Mr}$. XX, Chinese ambassador to Rwanda, Mr. XXX, Director General of Rwanda Agriculture Board, and Mr. XXX, Head of the expert team of the demonstration center, participated in the opening ceremony.

"News translation can entail the thorough-going transformation of the source text and the production of a new one designed to suit specific audiences according to the journalistic norms of the region" [9]. In Example 5, the translator does not translate the headline word by word, but conveys its meaning by using the phrase "nailed down" which means "to reach an agreement or a decision, usually after a lot of discussion" to deliver clear message with concise expressions and make explicit the connotation of the news.

The focus of news translation is to inform readers of what happens on the meeting instead of listing people attending the meeting. If all the information about attendants of the meeting in the Chinese version in Example 6 is translated, target readers may give up reading due to the reason that too many unfamiliar names and titles will be regarded as nuisance, in case of which the communicative goal of the news report will fail. Therefore, it will be better to omit some of the attendants and retain certain officials who hold significant positions.

\section{CONCLUSION}

This thesis takes translation of university webpage news as examples, attempting to explore English translation strategies for Chinese higher education institutes' website publicity with the guidance of Eco-translatology. It provides an interpretation of the translation process and translational eco-environment of university website publicity translation. It argues that translator should adapt to the translational eco-environment consisting of textual ecology and translation community before making adaptive selections and transformations in linguistic, cultural and communicative dimensions by employing corresponding translation strategies.

It has to be pointed out that further study is necessary to make this conclusion more objective and convincing, while more translation strategies can be explored to ensure the translation quality of the target texts.

\section{REFERENCES}

[1] G. Hu, Translation as adaptation and selection, Perspectives: Studies in Translatology, Vol.11, pp. 283-291, January 2003.

[2] G. Hu, An Approach to Translation as Adaptation and Selection. Wuhan: Hubei Education Press, 2004, p.222. (In Chinese)

[3] C. Nord, Translating as a Purposeful Activity: Functionalist Approaches Explained. Manchester: St. Jerome Publishing, 1997, p.12.

[4] S. N. Lehman-Wilzig \& M. Seletzky, Hard news, soft news, 'general' news: the necessity and utility of an intermediate classification, Journalism, vol. 2, p. 37=56, February 2010.

[5] Y. Liu, Translator's Adaptation and Selection: Translation Process Research for China's Global Communication. Beijing: People's Publishing House, 2010, p. 105. In Chinese. (In Chinese)

[6] G. Hu, Eco-Translatology Construction \& Interpretation. Beijing: The Commercial Press, 2013, p. 235. (In Chinese)

[7] E. Nida, A fresh look at translating, in Investigating Translation, A. Beeby, D. Ensinger and M. Presas Ed. Amsterdam / Philadelphia: John Benjamins Publishing Company, pp.3-12.

[8] L. Duan, How to Help Foreigners Know China. Beijing: China Reconstructs Press, 1988, p. 311.

[9] S. Bassnett \& E. Bielsa, Translation in Global News. Oxford: Routledge, 2009 , p. 84. 